OnLine Journal of Earth Sciences 12 (1): 1-7, 2018

ISSN: 1991-7708

(C) Medwell Journals, 2018

\title{
The Shoreline Changes in Syria Using Geographical Information System (GIS)
}

\author{
Mirna Sebat, Juliet Salloum and Bahjat Mohamad \\ Department of Geography, Faculty of Arts and Humanities, \\ Tishreen University, Lattakia, Syria
}

\begin{abstract}
Coastal erosion is of growing concern around the world when the shoreline moves landward, coastal erosion becomes a serious problem and the rate of change has to be calculated. To rotinom shoreline changes this study has been used Digital Shoreline Analysis System (DSAS) which is an extension for Arc GIS 10.3 Software developed by USUG. The GIS analysis for the period (1958-2010) shows that shoreline was generally retreating in the most of its parts reaching its highest point in the Al Kabir-Al Shamali River estuary. A total of transects built in the Al Kabir-Al Shamali River estuary have values less than zero (i.e., retreat shows the highest retreating rate almost $90 \mathrm{~m})$ and outside of the error margin $( \pm 10 \mathrm{~m})$ while the transect lines which have positive values higher than zero (i.e., advance shows of the highest degree in the Al-Faid land region). The value of EPR $(+1.81)$ shows the advanced shoreline and the transects are shown in gradients close to the red to indicate sedimentation.
\end{abstract}

Key words: Shoreline, retreat, advance, sedimentation, erosion, GIS, DSAS, EPR

\section{INTRODUCTION}

The Syrian shoreline is critical important being a waterfront for the Syrian coast. The changes in the shoreline constitute a real and accelerated threats to the vital system in the Syrian coast (Gormus et al., 2014). Where in the Syrian coast home for more than $11 \%$ of the total population and they contribute $12 \%$ of the gross national production considered as food chain, especially in protected crops and fruit orchards. And contribute about $38 \%$ of the national production of cement and $50 \%$ of oil refineries in the country. Where these facilities are located along the coast. Within 50 years, this shoreline witnessed an important changes. Therefore, it is very important to record and monitor the shoreline changes continuously with the most advanced technologies to develop a permanent perception and lasting consistent with future plans and projects for the development of the Syrian coast region and its management.

Characterization of the study area: The Syrian coastis located between two latitudes of $34^{\circ} .31$ and ' $35^{\circ} .37^{\prime}$ North of the equator circle and two longitudes of $36^{\circ} .13^{\prime}$ and $35^{\circ} .43^{\prime}$ East Green wich until the height (contour) line $\{250 \mathrm{~m}\}$ East in which the tyranny and recession of maritime had occurred in the Mediterranean. The existing marine sediments between the sea level and sea-level 250 $\mathrm{m}$ East of Jableh. Where the maximum nautical tyranny has occurred. The Calabrian1 50-250m (Al-Barouedi, 1984). The Syrian coastal region. Consisting of the coastal governorates Latakia and Tartous extend 183 long from Ras Al-Bassit "Al-Bodursuy" to the end of Tartuts District "Al-Araida" on the Lebanese border in the south. Divided into $\{93 \mathrm{~km}\}$ coast of Latakia District and $\{90 \mathrm{~km}\}$ of Tartous District.

Note that, the length $(183 \mathrm{~km})$ does not include the meanders in the shoreline and only represent an extension of basic lines which are a set of regular imaginary lines or straightlines related to the maximum points located on the minimum of the island toward the sea that separates the internal waters of the territorial (Fig. 1).

Origin: The preparation of the student on the basis of satellite image. The ability of discrimination $(\mathrm{Lm})$. It also classified the reliefin the coastal region according to map showing the morphology of the shoreline depending on the available geo morphological map and visual interpretation of satellite images. As the use of topographic map, contour lines and geological map. Also, It concluded a lot of investigations and monitoring operations on the ground in many regions (Fig. 2).

As shown in Table 1 that the rocky cliffs constitute $(9.8 \%)$ of the coast. In estimated distant $(18 \mathrm{~km})$ including of $(13 \mathrm{~km})$ Amphibole rocks $(5 \mathrm{~km})$ of limestone rocks. Whereas the sand beach compose about $(36.1 \%)$ of the coast. In estimated distance

Corresponding Author: Mirna Sebat, Department of Geography, Faculty of Arts and Humanities, Tishreen University, Lattakia, Syria 


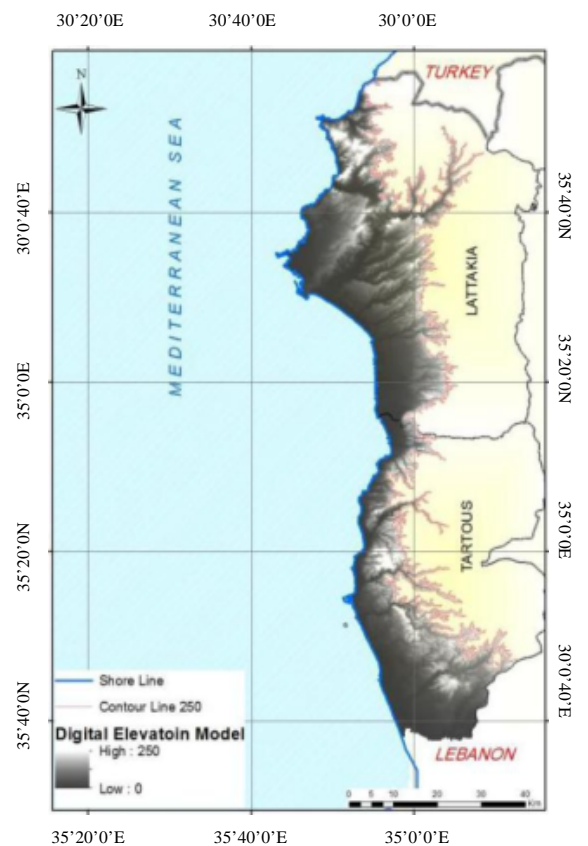

Fig. 1: Clarify the geographical reality of the study area: origin the preparation of the student on the basis f satellite image. The ability of discrimination

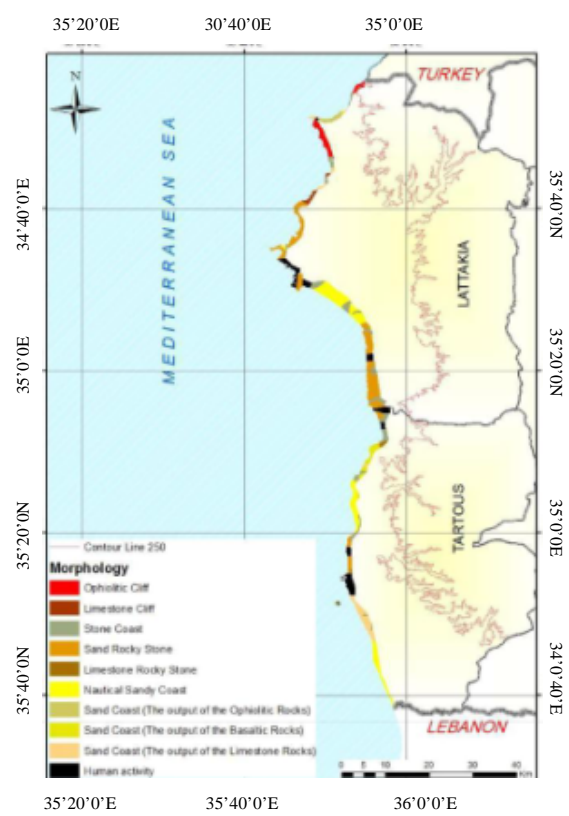

Fig. 2: Clarify themorphology of the Syrian shoreline. Origin: the preparation of the student depending on geological map. 1/50000

$\mathrm{km})$ along the Syrian coast. The human activity estimated about $(16.9 \%)$ of the coast area $(31 \mathrm{~km})$ and beach (pebble) compose $(7.7 \%)$ of the Syrianc oastand in estimated distant $(14 \mathrm{~km})$. The rocky beaches compose
Table 1: Clarify the morphology and the perception of each ears in the Syrian shoreline

\begin{tabular}{lcc}
\hline Shoreline morphology (\%) & Distance by $(\mathrm{km})$ & The perception \\
\hline Nautical sand beach & 37 & 20.2 \\
Sand beach resulting from & 15 & 8.2 \\
Limestone rocks & & \\
Sand beach resulting & 10 & 5.5 \\
From basaltic rocks & & \\
Sand beach resulting from & 4 & 2.2 \\
Amphibole rocks & & \\
Cliff & 13 & 7.1 \\
Limestone cliff & 5 & 2.7 \\
Human activity & 31 & 16.9 \\
Sand rock beach & 51 & 27.9 \\
Limestone rock beach & 2 & 1.1 \\
Beach (Pebble) & 14 & 7.7 \\
Total & 183 & 100 \\
\hline
\end{tabular}

$(29 \%)$ of the coast. Beaches as result of sand rock (51\%) and $(2 \%)$ as result of limestone to form the rocky beaches of the Syrian coast near $(53 \mathrm{~km})$.

\section{MATERIALS AND METHODS}

Data of remote sensing: The study mainly, depended on high-resolution satellite image $(1 \mathrm{~m})$ of (Ikonos) type. Taken in 2010 referent and geographically projection. The the shoreline was drawn accurately to compare and match it with the shoreline drawn on the Ariel photo (white-black) taken in 1956. Note that, all Aerial photos geo-referenced depending on the modern referent space photo in order to compare the landmarks in the two photos such as an intersection or corner of the building through the geographic information system (Anonymous, 2005). The errors associated with accuracy of vertical photography for Aerial photos, the reflection of the image, the sources of other errors such as heat, height and pressure exerted on the camera and the overlap among all these errors can lead to distortions in the Aerial photo (Chaaban et al., 2012).

So, we concluded the margin of errors in this study about $(1 \mathrm{~m})$ depending on the accuracy of the aerial photo.These errors were taken into account in the graph and the interpretation of the results.

Data processing: To determine the exact line of the beach andto monitor his changes is essential for planning and management of the coastal zone. In this study, we compare between the two shorelines during (1958-2010) as follow: after the referent of the aerial photo depending on common points with the geo-referenced satellite image. Taking in to the account the errors in referent with in the allowed values. The written chips for the shorelines were established in the program (Arc-catalog) and then graphic in Arc-map.

These changes showed varying degree on the aerial and satellite images. To identify the retreat areas in the shoreline and the areas where the land overcome the sea. 
Through the changes of erosion or sedimentation or actual human activity. On the basis of difference of and in the nature of the rocks. We identified five areas: Ali Issawiyah area, Al-Faid land area, Al-Kabir Al-Shamali River, Ibn Hani area, Al Basia area.

\section{The indicators used in the research}

EPR: The rate of the end point calculated by dividing the distance between the movement of the shoreline and time elapsed between the oldest and the latest measurements (the oldest and the newest shoreline) (Armaroli et al., 2004).

The main advantage for EPR is easily calculated and require the minimum amount of the coastal data (two shorelines). The main disadvantage is that in cases there is more than two shorelines. The information related to the conduct of the shoreline. Which provided by the additional beaches and the changes in the size of the direction of the beach or the cyclical fluctuations of behavior be neglected. But in this study, the data of two shoreline were used to overcome the technical defects.

DSAS: It stands for Digital Shoreline Analysis System. It is intended for the analysis of digital for shoreline and it is an extension support the natural function of the program (ESRI ArcGIS) users can calculated the statistics of the rate of changes of shoreline from different series of time of shoreline locations. The extension was designed to assist the analysis of historical changes to the beach. The DSAS system work through the establishment of perpendicular segments (Chand and Acharya, 2010) and then calculate the rate of changes and statistics associated with the chart of data. DSAS calculate a lot of statistical indicators such as (LRR-JKR-EPR) (NASA US Geological Survey).

\section{RESULTS AND DISCUSSION}

Many scientists studied the coastal erosion and they suggested many ways to measure the coastal retreat. The most common way is the baseline method and it was chosen in this research. This method is defined as the cross section method and used by Dolan et al. (1978). Where the baseline was chosen parallel to the shoreline And adopted for all maps and from near area of the shorelines during (1958-2010) to account the degree of changes by the meditation and perpendicular diversion with the line segments that have been created to conclude the rates of change. The establishment of transections and standards of changes was automatically using special programs such as DSAS which attached to program ArcGIS. This extension contains elements identified the baseline and produced perpendicular videos to give clear clarification of shoreline and rate for its changes along the segments in the analysis the rate of changes of the shoreline during the study period was calculated by the statistical technique the End Point Rate (EPR) (Dolan et al., 1991). Specific classification was adopted to clarify the values of EPR in selected areas of the study. The value zero indicates the full match of the shorelines. There is no erosion no sedimentation.

The negative values have been given green colortones to indicates the erosion and aclear retreat of shoreline. While the positive values indicates the sedimentation in area and overcome the land over the sea to show the segments in red and his tones. It is to be noted that the cuts take to show the classification clearer and with more color tones to clarify accurately the used classification.

Al Issawiyh area: At Al Soda stream, the shoreline distinguished crooked and far from straight the geological characteristics of the coastal zone did not response to erosion operations to weaken the influence of factors of the erosion on solid rock in the coastal range of Ampholible rocks. Therefore, the shoreline did not show any changes and it showed full match of shorelines in the is sawiya area during (1958-2010) (Fig. 3). The baseline was established in parallel with the general directions of the shoreline all transects were built on regular basis and with a distance $(5 \mathrm{~m})$ along the beach and in length $(100 \mathrm{~m})$ at the end all transects (1046 transects) built and referented in known order from East to West to give (EPR) the zero value along the line (Chand and Acharya, 2010). Here, the shoreline did not show any progress or retreat. But full match of the shorelines to be assured by the zero value of EPR.

Al Faid land area: It was noted the domination of sedimentation and overcome the land over the sea (1958-2010) where the maximum amount of sedimentation about $(15 \mathrm{~m})$ and the the minimum after the patch $(12 \mathrm{~m})$ (Fig. 3) caused by River Debris of Musa pond which worked to fill the the valley with river supplements and the erosion operations as a sediment factor has increased. When they met with the shoreline in oblique or parallel angle as in $\mathrm{Al}$ Fakhorah and Ibn Hani ports with no doubt these ports were deeper then now because of the plenty of streams and valleys which have contributed to fill it with River Debris. With the knowledge that they stillused 

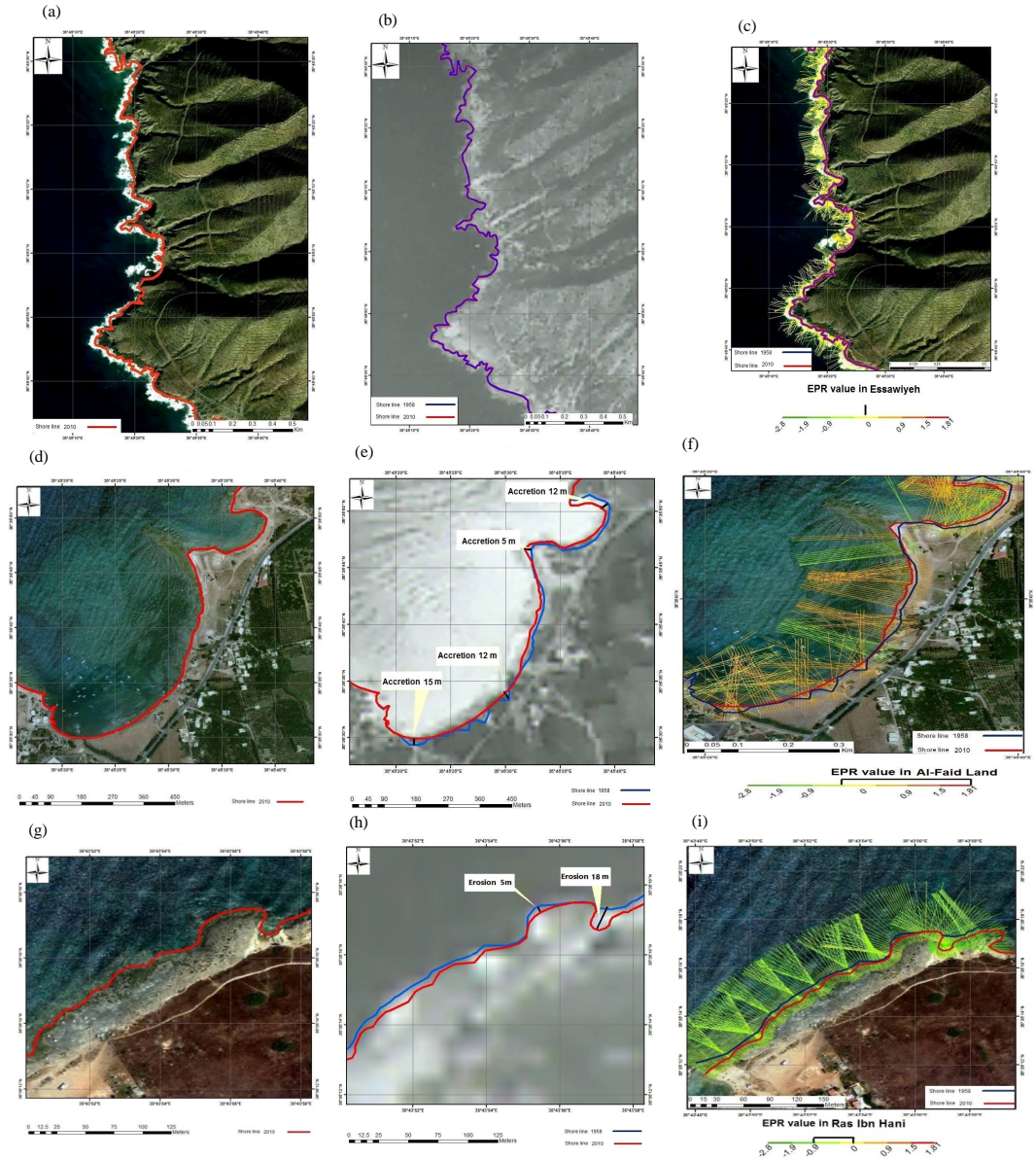

Fig. 3: a) The shore line in Al Issawiyah area in 2010; b) Comparison of the shore line in Al Issawiyah area between 1958-2010; c) The value of EPR in Al Issawiyah area depending on the DSAS tool; d) The shore line in Al Faid land area of 2010 ; e) Compared to the shore line in Al Faid land between 1958 and 2010; f) The value of EPR in Al Faid land area depending on the DSAS tool; g) The shore line in Ibn Hani area in 2010; h) Comparison of the shore line in Ibn Hani area between 1958-2010 and i) The value of EPR in Ibn Hani area depending on the DSAS tool

by the fishing ships and we can see along the port the shards and that's why we call it Al Fakhorah port. Here, the erosion and sedimentation areas showed clearly when the comparison between the two shorelines (1958-2010) on the Ariel and satellite photos in Al Faid land. The equipment DSAS has produced (287) transects directed vertically in the shoreline with distance $(5 \mathrm{~m})$ and with length of transects (200) was chosent of it with the shoreline. Note that the total transects showed the overcome of land over the sea and it showed the transects colortones, close to the red color. EPR give positive values. The sedimentation is domination and the maximum value is $(\mathrm{EPR}=+1.81)$ in then or thern section of the area and this is what have been previously interpreted and the minimum $(\mathrm{EPR}=$ 0.07 ) indicates of the erosion about $(5 \mathrm{~m})$ (Fig. 3 ).
Ibn Hani area: The maritime erosion is dominated in spite of that sedimentation must occurred to the East of the head advancing the sea at the expense of the mainland of the shore line by $(5-18 \mathrm{~m})$ during the period between 1958-2010 and because the of the low diversion in the area and the weak resistance of Paleogene limestone rocks and the the presence of tectonic cracks in the area directed from south to north has contributed in smashing the limestone and in addition to the chemical erosion to degree the amount of retreat and erosion to $(18 \mathrm{~m})$ (Fig. 3). And the changes appeared in the comparison between the shorelines. The maximum value $(\mathrm{EPR}=0)$ and the minimum value is $(E P R=-1)$ there is no value more than zero, so. There is no sedimentation in this area here the baseline had determined and 38 transects were built 

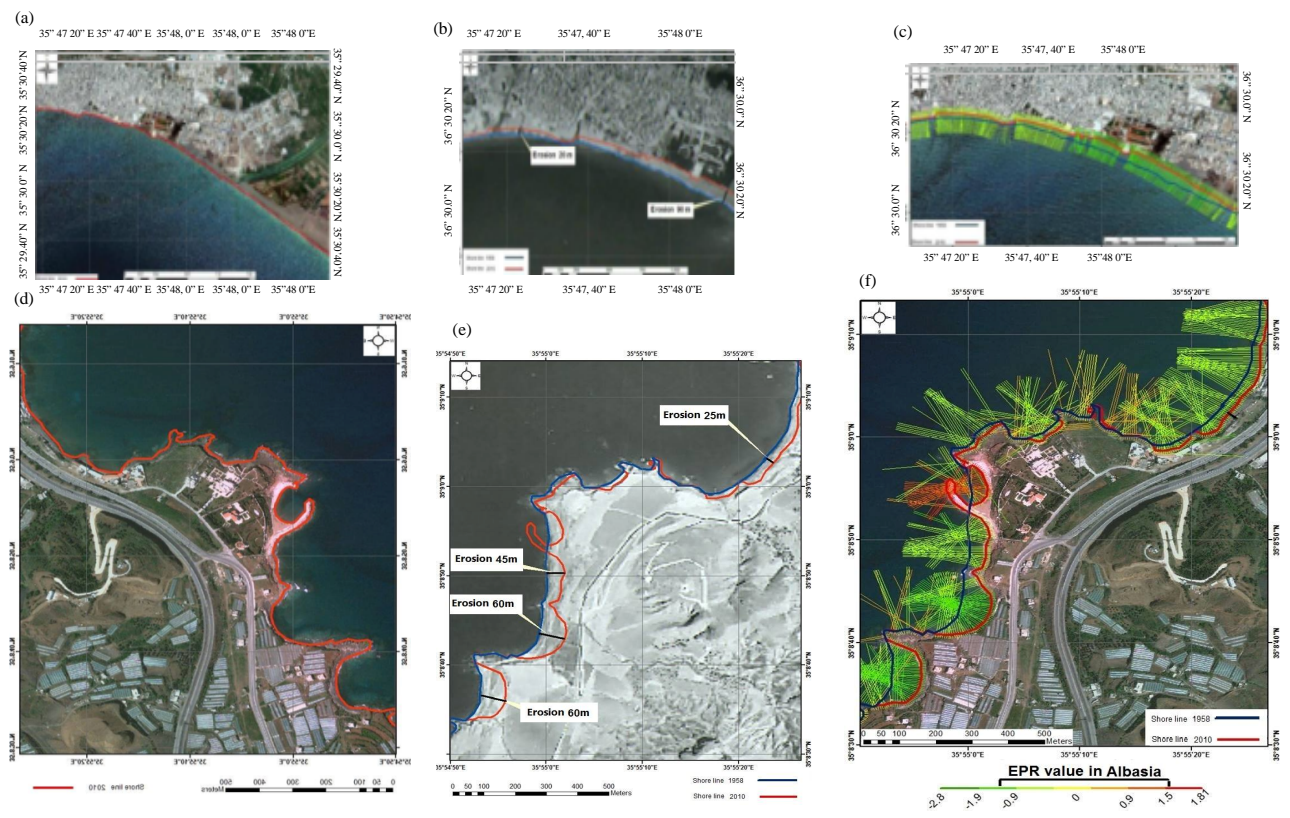

Fig. 4: a) The shore line in Al-Kabir Al-Shamali River in 2010; b) Ccompared to the shore line in Al-Kabir Al-Shamali River between 1958-2010; c) The value of EPR, In Al-Kabir al-Shamali River depending on the tool DSAS; d) Shoreline in the area of Al Basia in 2010; e) Compared to the shoreline in the Al Basia area between 1958 and 2010 and $\mathrm{f}$ ) the value of EPR in the Al Basia area depending on the DSAS tool

in known order from East to West with distance of $(1 \mathrm{~m})$ and a length $(75 \mathrm{~m})$ for transects to show the transects in green which indicates the domination of erosion and the map (Fig. 3).

Al Kabir-Al Shamali River: We noticed that after the comparis on between the two shorelines on Aerial photo clear and intense erosion and retreat of the shoreline about $(20-90 \mathrm{~m})$ that's helped to weaken the resistance of sand rock of erosion and the low diversion (Fig. 4). The location of the shoreline according to the waves and winds direction and currents played the main role in increasing the erosion in this area it cannot be notice the sediments in this area even though that Al-Kabir Alshamali River is considered one of the most important ports and the bigger coastal permanent River. But the water prevented by 16 Tishreen dam to use it for agriculture issues cause the lower water income to the sea. And the amount of drained sediments to the coast and the river changes his pour between (1958-2010) after he was towards North to the South. And these changes will be increased during the near future form the intensity of the negative effects of the world climatic changes and increase sea level to make this area of a high dangerous zone because of any changes in the near future. After the comparison between the two shoreline clarify there treat and the domination of the erosion over the sedimentation and transects showed in (609) in $(5 \mathrm{~m})$ along the beach with length $(200 \mathrm{~m})$ and in the known order from East to West to give the EPR negative values along the line. The maximum value between the chosen areas for the study $(\mathrm{EPR}=-2.8)$ faces the maximum recorded value $(90 \mathrm{~m})$ and the highest value $(E P R=-0.8)$. All the transects have negative values and the EPR zero value, so, there is no full match for the shoreline and there is no sediments but the domination of erosion in the area. The transects showed in dark green indicates the intensity of the erosion in the area (Fig. 4).

Al Basia area: It is noted that the domination of the erosion after the comparison between the two shoreline of $(25-60 \mathrm{~m})$ to show the weaken resistance of the basaltic rocks. The balloon basaltic intervals which determines the bigger part of the morphology of the South section of the beach. It has been encrypted and broken down as a result of the warm and humid environments and the effects of the rain but the difference in erosion and retreat amount back to the difference in divert degree. Therefore, we notice that the highest coastal cliffs distinguished with slowly retreat 
of the lan dincompare with the lower ones. The match in the erosion rates and the match of structural of the rock (Fig. 4). The equipment DSAS produced about (513) transects vertical on the shoreline in distance $(5 \mathrm{~m})$ and length of transects $(200 \mathrm{~m})$ was chosen to match the shoreline. To notice that the total transects appeared in green to show clear retreat of the shoreline as the segment show in red tones to give the EPR positive value too. And the overcome of the land over the sea. The maximum value $\mathrm{EPR}=+1.61$ indicates on sediments in the small Al Bas Gulf. Between the crossed tower in the South where the ship home. And the Roman tower installed in hole was constructed in natural rocks and this rocks go deep in the sea to form a good barrier for the ships and exchange the different maritime business in this Gulf. And we can consider it as a natural shelter. But it was prepared for temporary business and to provide the main needs. This percent here is an artificial human. The minimum value (EPR $=-1.4)$ refer to intense erosion faces the value $(60 \mathrm{~m})$ Fig. 4. After comparison the statistical result for thee quipment DSAS with the degrees of erosion and sedimentation that has been recorded when we compare the two shoreline between (1958-2010) we have the highest statistical recorded value for erosion showed in the Al-Kabir Al Shamali River area and that matches with the highest recorded erosion values $(90 \mathrm{~m})$ in the same area. But the retreat and erosion has increased in the area, especially, after the construction of 16 Tishreen dam in 1985. The amount of the sediments which was received by the sea has decreased because of the construction of the 16 Tishreen dam to occur the domination of the erosion over the sedimentation. With the concern the margin of errorsin every chosen area of the study. The highest degree of sedimentation between the chosen area of the study recorded in $\mathrm{Al}$ Faid land $(15 \mathrm{~m})$ to take EPR the highest value $(+1.81)$.

\section{CONCLUSION}

The study of the historical data of the shoreline could be use to determine the dominated coastal process in which coastal changes occurs and it can be used as a guide to the index and dynamics of shoreline. Thus, to extra polate the future changes of the shoreline and constant monitoring for shoreline changes today is essential to under stand the process for the investment, planning and good management for coastal region. The integration of modern technology today and remote sensing with Geographic Information System (GIS) demonstrated a great ability to give useful approach to study the shoreline changes. Thus, the study of the coasts and changes is critical important to conceive of what is happening and what can be done to protect in the light of current and emerging data expected.

\section{SUGGESTIONS}

To monitor of the part exposed to and try to address the continuing and through the establishment of a pier and there inforcing concerts mortgages fixeds tone to prevent leakage of the water to access to rock. Proper and good administration of coastal regions as an example if it was to prevent the construction of the facilities and buildings near the beach. We can avoid many future problems concerning erosion result from storm until structural corrosion even if it temporary.

The dimensions of the facilities roads bridges on the impact of the maritime erosion and risks through building marine barriers to protect properly from storm waves and coastal changes. To work in installed the sand in the region through the transplant environment. And that the protection of the urban center of the going March of the sand where that plant is working to protect the shoreline of retreat before the operation of maritime insisted. Interference in the natural sediments transfer process using the means of protection as the sand barriers and deep wall to strengthen the beach. Artificial nutrition is one of the forms of protection of the beaches any protection that is artificially brought the sand from an external sources which it put in the coastal environment.

\section{REFERENCES}

Al Barouedi, M.S., 1984. The Syrian coast (Geomorphology study). Ph.D Thesis, Ain Shams University, Cairo, Egypt.

Anonymous, 2005. User guide and tutorial for the digital shoreline analysis system (DSAS) version 3.2 extension for ArcGIS10.3. NASA Federal Agency, Washington D.C., USA. https:// woodshole.er.usgs.gov/project-pages/DSAS/ver sion3/images/pdf/DSASv3_2.pdf

Armaroli, C., P. Ciavola, Y. Balouin and M. Gatti, 2004. An integrated study of shoreline variability using GIS and ARGUS techniques. J. Coastal Res., 1: 473-477. 
Chaaban, F., H. Darwishe, Y. Battiau-Queney, B. Louche and E. Masson et al., 2012. Using ArcGIS® modelbuilder and aerial photographs to measure coastline retreat and advance: North of France. J. Coastal Res., 28: 1567-1579.

Chand, P. and P. Acharya, 2010. Shoreline change and sea level rise along coast of Bhitarkanika wildlife sanctuary, Orissa: An analytical approach of remote sensing and statistical techniques. Intl. J. Geomatics Geosci., 1: 436-455.
Dolan, R., B. Hayden and J. Heywood, 1978. A new photogrammetric method for determining shoreline erosion. Coastal Eng., 2: 21-39.

Dolan, R., M.S. Fenster and S.J. Holme, 1991. Temporal analysis of shoreline recession and accretion. $\mathrm{J}$. Coastal Res., 7: 723-744.

Gormus, K.S., S.H. Kutoglu, D.Z. Seker, I.H. Ozolcer and M. Oruc et al., 2014. Temporal analysis of coastal erosion in Turkey: A case study Karasu coastal region. J. Coastal Conserv., 18: 399-414. 